\title{
Uden mur i 20 år
}

Muren, der delte Europa, er faldet. Det er en gammel nyhed, 20 år i disse dage.

Men for mange er det også en nyhed, at Muren overhovedet har været der. En hel generation er vokset op, og for mange unge er det allerede ufatteligt, at deres forældres og bedsteforældres og oldeforældres generationer kunne indrette sig så vanvittigt, at de lod Europa dele af en mur og et jerntæppe mellem $\emptyset_{\text {st }}$ og Vest.

Men sådan var det - for ikke så længe siden.

Og så den rigtigt dårlige nyhed: Skønt Muren er væk, har et par af de totalitære samfund overlevet.

Hviderusland, som opretholder et benhårdt 'sovjetisk' system, er ikke længere væk fra Danmark end Frankrig. Og Ukraine fornægter også nærmest den udvikling, som har bevist, at demokratiske markedsøkonomier er mere effektive og er bedre til at indfri deres befolkningers iboende ønsker om råderum, økonomisk og politisk.

Det ny Europa er selv sagt temaet for dette nummer af udenrigs.

For 20 år siden var der mennesker - både politiske ledere, forskere og vælgere - som frarådede, at
Europa igen skulle få et forenet, stort og stærkt Tyskland i sin midte. Hvordan går det i dag? Og hvordan går det i det Centraleuropa, der ikke overvejede længe, om det ville forblive i Ruslands skygge eller søge ind i samarbejde med det gamle Vesteuropa?

I dag har vi ét Europa. Og dog et Europa, hvor Rusland giver indtryk af besvær med at finde sin egen plads og tilknytning, og hvor både det traditionelle 'Vest' og det gamle 'Øst' synes urolige for at opleve gamle mønstre titte frem.

Hvis regeringer uomtvisteligt er usikre på, hvordan de skal træde, kan de ikke være i tvivl om, at deres borgere i stort tal har vidst at gøre brug af de nye muligheder.

Det er et privilegium af historiske dimensioner at have oplevet Muren falde. Men også en forpligtelse til at sikre, at Europa ikke igen skal blive delt. Det kræver samarbejde og allehånde politiske $\mathrm{og} \varnothing \mathrm{konomiske} \mathrm{og}$ kulturelle forbindelseslinjer dér, hvor et iskoldt jerntæppe førhen delte vores verden. Hvordan går det?

Redaktionen 